UDC: $811.111^{\prime 2} 276.3 \quad$ https://doi.org/10.22190/JTESAP1901063S

\title{
ON TRANSLATING CAT AND DOG IDIOMS IN ENGLISH AND SERBIAN
}

\author{
Jelena Šajinović Novaković \\ University of Banja Luka, Bosnia and Herzegovina \\ E-Mail: jelena.sajinovic@gmail.com
}

\begin{abstract}
The aim of this paper is to analyse feline (primarily cat) and canine idioms in English and Serbian phraseological dictionaries. Idioms are an integral part of any language, and therefore knowing them means being able to understand culture they come from and sound more natural like native speakers. Semantically speaking, they express a nation's perception of the inner and outer world surrounding it. For the importance they have in linguistic and cultural life of a nation they have been the focus of many studies in which they were primarily analysed in terms of their origin and expressive function. We believe that the analysis of the existing bilingual dictionaries will shed light on the problems translators sometimes face in this laborious process of idiom translation. One of the subsidiary purposes of this paper is to draw attention to 50 cat and dog idioms (36 animal idioms in Serbian and 14 in English) that have not been transferred from the source to the target language yet.
\end{abstract}

Key words: dog idioms, cat idioms, translation.

\section{INTRODUCTION}

"Since the culture of a nation permeates the language, the best way to understand a culture is through the language. And the best way to learn about the values and beliefs of a nation is through fixed expressions" (Новаковић, Томић 2015, 488) or phraseological units or idioms. For Baker $(1992,63)$, "they are frozen patterns of language which allow little or no variation in form ... and often carry meanings which cannot be deduced from their individual components".

"Animalistic phraseology is a huge layer of phraseological unit and is one of the most common forms of the language nomination, because it is through comparing ourselves with the animal world that a person comprehends the reality surrounding him/her, and, to a certain extent, comprehends himself/herself in this reality" (Varlamova et al. 2017: 478). It reflects "the centuries-old observations of a person over the appearance and habits and behavior of animals, show the attitude of a person to their 'smaller brothers', thus being a cultural-informational fund in each language" (Varlamova et al. 2017: 479). The job of the translator is to unlock and share that fund with other nations in the first place by understanding these phraseological phrases, and in the second by transferring them from one language to another. In that process, he/she has to be the learner eager to dig deep to find answers to the questions needed to carry out their job properly, "to produce on his readers an effect as close as possible to that obtained on the readers of the original" 
(Newmark, 1981:39). To do so, the translator has to be familiar with cultural connotations in both languages. For example, cats and dogs make good pets in both Serbian and English culture but the two cultures do not necessarily have to have the same connotations and interpretations of these animals. Back in the Middle Ages, cats were generally regarded as negative creatures since they were brought into relation with witchcraft and seen as evil, envious and cunning. Under the influence of the Christian ideology, where black is regarded as a sign of bad luck, certain cultures like Serbian, began to identify a black cat with misfortune especially if the black cat cross someone's path. The belief that black cats bring bad luck is also held in the United States while in the UK it is the opposite - a black cat signifies good fortune and good luck. It is not surprising that a great number of cat idioms in both languages have negative connotations and refer to a bad character, criticising, anxiety and futility. Although seemingly affectionate, idioms with zoonyms like a kitten have also acquired a negative connotation as they usually refer only to women as sexual objects: Kakva maca! (What a kitten!). In some cultures like Serbian people do not value dogs. That is why dog idioms tend to have derogatory connotations.

The translator has to think about all this when embarking on this process of translating "which requests a lot of skills and knowledge not only of the source language and culture but also of the target language" (Новаковић, Томић 2015: 488). For, no matter how skilful the translator is, they may sometimes face "the main problems that idiomatic and fixed expressions pose in translation... the ability to recognise and interpret an idiom correctly; and the difficulties involved in rendering the various aspects of meaning that an idiom... conveys into the target language" (Baker 1992: 65). To solve the first problem, the translator will probably use a good monolingual dictionary of idioms, but to solve the second one, they will have to dig deeper. One of the things to do is to classify the idioms according to the semantic fields they pertain to. Such a classification would pave the way to identification of semantically equivalent idiomatic expressions in the source and target language, regardless of their form. It would also help the translators fill the existing translation gaps in dictionaries.

\section{METHODS}

The present study has collected and analysed 153 idioms for two animals (a cat and a dog) in English and Serbian. The material we used for the analysis is based on the data found in phraseological dictionaries of the English and Serbian language. The study has been conducted in three stages. The first stage comprises data collection from Cambridge International Dictionary of Idioms (1998), The Oxford Dictionary of Idioms (2004), Frazeološki rječnik hrvatskoga ili srpskoga jezika (1982), Српско-енглески речник идиома (2007) and Енглеско-српски фразеолошки речник (2007) and some other dictionaries that are listed in section Reference. In the next stage we discuss strategies used for transferring phraseological units from the source language to the target language. In the last stage idioms are described in terms of semantic fields they pertain to in both languages. Idiom figures are given in brackets. 


\section{RESULTS}

The corpus for this research includes $56 \mathrm{dog}$ and 35 cat idioms in Serbian and $35 \mathrm{dog}$ and 27 cat idioms in English. Relying on the strategies proposed by Baker (1992, 71-78) we identified three different ways in which these cat and dog idioms were transferred from the source language to the target language. The first group entails the idioms that are translated with idioms of similar meaning and form. The idioms from this group show complete equivalence and contain the "identity of congruent denotational, connotational, expressive and stylistic meanings of the idioms compared" (Gläser 1984: 126). The second group entails the idioms translated with idioms of similar meaning but dissimilar form (36). They show partial equivalence and usually have a different animal. The third group entails the idioms that are translated by paraphrasing and show no equivalence. Finally, there are a great number of idioms that have not been translated yet (50), making $1 / 3$ of the total number of analysed examples.

\subsection{Idioms of similar meaning and form}

A number of idioms in English and Serbian (38) have almost the same lexical items (including the same zoonoym). That is the reason why they are easily translated from the source into the target language: When the cat's away, the mice will play (Gdje mačke nema, miševi kolo vode); Has the cat got your tongue? (Je li ti maca odgrizla jezik?); The dogs days (pasje vrijeme); The dog life (pasji život); Dog-tired (umoran kao pas); Igrati se kao mačka sa mišem (Play cat and mouse); Nemati ni kučeta ni mačeta (he hasn't got a dog to lick his dish); Raditi kao pas (to work like a dog); Crknuti/Umrijeti kao pas (to die like a dog); Pasja vjera/Kučkin sin (a son of a bitch); Pas koji laje ne ujeda (a barking dog seldom bites).

\subsection{Idioms of similar meaning but dissimilar form}

It is quite usual to find an idiom in the target language that is similar in meaning to that of the source language (36) but different in the choice of lexical items: obilaziti kao mačak oko vrele kaše (to beat about the bush); prebiti kao mačku (to beat the living daylight out of someone), kao mačka repom (to give someone a lick and a promise), ofucan kao papudžijski mačak (down-at-the-heel); lagati kao pas (to lie through one's teeth), ispsovati na pasja kola (to haul over the coals); it's raining cats and dogs (lije kao iz kabla); play cat and mouse (vući za nos). Several phraseological units of English and Serbian that have the same meaning, but contain different zoonyms, may also join this group. These idioms give us a clear reflection of the culture of the target language since they show the perception people of a specific nation, in this case Serbian, or English have of the world, especially animals. Idioms with dogs in English have their counteparts in Serbian. Yet, in Serbian idioms with animals other than a dog like koka (hen), jarac (goat), konj (horse), lav (lion) convey the same meaning: Dog eat dog (Čovjek je čovjeku vuk); Every dog has its day (i ćorava koka zrno nađe); Throw to the dogs (učiniti žrtvenim jarcem); You can't teach old dog new tricks (mator se konj ne uči); Let sleeping dogs lie (ne diraj lava dok spava); Put the cat among the pigeons (baciti kost među pse); Like a scalded cat (juriti kao muha bez glave). There are some other dissimilarities between perception in English and Serbian. For example, when you are hungry, Serbian people would compare you to a dog to indicate how hungry you are: gladan kao pas, whereas English people would say that you are as hungry as a hunter/bear/wolf. 


\subsection{Paraphrase}

According to Baker (1992:74) paraphrasing is by far the most common way of translating idioms when a match cannot be found in the target language. We could question this statement of hers since the translation of this type occurred only in 1/5 (29 entries) out of total 153. The idioms like a cat on a hot tin roof (uzrujan), grin like a Cheshire cat (osmjehivati se da se vide desni), a dog's breakfast/dinner (fušeraj), the hair of the dog (pij još da rastjeraš mamurluk), the top dog (onaj koji zapovijeda), were all paraphrased when transferred to the target language. Some of them like grin like a Cheshire cat $^{1}$ are very culture-specific (Baker 1992: 68), and to transfer them to the target language the translator has to find the idiom with similar semantics. Sometimes, such idioms are untranslatable. Coping with these animal idioms, the translator sometimes uses a very literal translation as in: mačku kako god baciš, ona se dočeka na noge (he's like a cat, fling him which way he will lend on his legs), ko sa psima leže, pun buva ustaje (if you lie down with dogs you will get up fleas), pojela maca (cat did it), Why keep a dog and bark yourself (čemu posluga ako radiš sam) or an arbitrary translation that semantically weakens the idiom from the source language. For example, the idiom $k o$ kusih pasa has a negative connotation in Serbian which cannot be sensed in English since the dictionary offers the adjective galore as the equivalent substitute for the Serbian idiom. It is the same is with the idiom $a$ dog's dinner (fušeraj) ${ }^{2}$. We believe that the translator could have found better solutions if they had classified idioms of the source and target language according to the semantic fields they belong to the way we did. That would help him/her find the equivalents and learn something about the cultural perception of the world in the source and target language.

\section{SEMANTIC FIELDS}

Dog idioms in Serbian leave you with a negative impression about dogs in Serbian culture in which they are not appreciated. The majority of dog-based idioms present negative images such as suffering, criticism, bad character, futility, and suchlike. Notwithstanding a deep rooted belief that the dog is the man's best friend we could identify only one idiom in Serbian that describes that relationship between humans and dogs (veran pas). However, there is another idiom from the same semantic field but with a negative connotation (pasja braća $=$ neprijatelji). The rest of the analysed idioms could be divided in the following fields: intensity: (14) mučiti se kao pas, gladan kao pas, umoran kao pas, trpjeti kao pas, raditi kao pas, tresti se kao kuja u vodenici, mršav kao pas, pasje vrijeme, pasje vrućine, pasa zima, ni pas sa maslom ne bi pojeo, ne bi ga nadlajalo ni 9 pasa, lagati kao pas, ne vrijedi ni kera; character: (7) pasja vjera, kučkin sin, pasja capa, pasja vjera, prijepiti se kao čičak u pasji rep, pas koji laje ne ujeda, pas rekao, pas porekao; criticism: (5) izgrditi na pasje ime, grditi na pasja preskakala, izgrditi na pasji opanak, grditi na pasje obojke, izgrditi na pasja usta, misfortune: (5) umrijeti kao posljednje pseto, živjeti kao pas, crknuti kao pas, otići pasjom prtinom, umrijeti kao pas; freedom: (4) kao pas pušten sa lanca, kao pas na lancu, protjerati kera, pustiti psa sa lanca; futility: (3) landrati kao jalov

\footnotetext{
1 The Cheshire cat is a character in Lewis Carroll's book Alice in Wonderland and is famous for its big smile .

${ }^{2}$ The image is of a dog's meal of jumbled- up scraps (Oxford 2004)
} 
pas, skitati se kao gluha kučka, vući se kao gluha kučka, kad stari pas laje, treba vidjeti šta je; quantity: (3) ko kusih pasa, ni bijesan pas, ni gluhe kučke, having/not having: (2) nema za šta pas da ga ujede, nemati ni kučeta ni mačeta; deception: (2) ne veruj snu koliko ni psu, ne laje kuca sela radi, već sebe radi; contempt: (2) držati koliko do pasje šape, mariti kao pas za petu nogu; reason: (2) neće na prazno ni pas lajati, kad stari pas laje, treba vidjeti šta je; violence: (2) isprebijati na pasje ime, ubiti kao psa; manner: (1) postupati kao sa psom; equality: (1) pas od psa ne jede; reputation: (1) prosuti pasju čorbu; conflict: (1) gledati se kao pas i mačka; weakness: (1) puzati kao pas.

Although dogs are appreciated in English culture nowadays they probably were not as appreciated at the time these idioms appeared since the images related to a dog in English idiomatic expressions are also rather negative and refer to various semantic fields. Those that connote well-being like a dog with two tails are quite rare: intensity (4) such as dogtired, dogs days, to work like a dog, puppy love; opportunity (3) such as every dog has its day, not to have a dog's chance, while two dogs are fighting for a bone, a third runs for it; communication (2) such as a shaggy dog story, to go to see a man about the dog; selfinterest (2) such as dog in the manger, dog eat dog; physical appearance (2) dressed like a dog's dinner; puppy fat; age (2) such as you can't teach an old dog new tricks; there's life in the old dog yet; reputation (1) give a dog a bad name; misfortune (1) it's a dog's life; conflict (1) call off the dogs; deception (1) lie doggo; futility (1) why keep a dog and bark yourself; power (1) the top dog; caution (1) let the sleeping dogs lie; happiness (1) like a dog with two tails; health (1) as sick as a dog; warfare (1) the dogs of war; success/failure (1) go to the dogs; victimhood (1) throw to the dogs; annoyance (1) be in the doghouse; help (1) help a lame dog over a stile; business (1) a dog and a pony show; permission (1) let the dog see the rabbit; exaggeration (1) to tail wagging the dog; conceit (1) put on the dog; time (1) in dog's age; food (1) hot dog; quantity (1) the hair of the dog.

A good number of cat-based idioms in Serbian also have a negative connotation and refer to an unattractive physical apperance and a character like greediness or indecision and many other: appearance/character (6) izgledati kao prebijena mačka, ofucan kao papudžijski mačak, što god maca omaci, ono miševe lovi,mačku kako god baciš, ona se dočeka na noge žustar kao mačka,kakva maca; intensity (5) izvući mačku rep, zaljubiti se kao mačak; lud kao februarski mačak, kao mačak repom, smrdjeti kao mačeti sirće, prebiti kao mačku; success (2) prvi se mačići u vodu bacaju; gnjaviti mačiće; misfortune (2) gdje je strvina, tu se i psi kupe; povući mačka za rep; power (2) igrati se kao mačka sa mišem; mačka ima devet života; equality (2) doće maca na vratanca; uzmao davao, sa mačkama spavao; importance (2) mačji kašalj; bolje na mačku glava, nego na lavu rep; having/not having (2) nemati ni kučeta, ni mačeta; pojela maca; greediness (2) i mačku bi pomuzao; mačku je malo goveđa glava; secrecy (1) kupovati mačka u vreći; indecision (1) obilaziti kao mačak oko vrele kaše; contempt (1) objesiti mačku o rep; authority (1) kad mačke nema, miševi kolo vode; futility (1) ići kao ćorava mačka; deception (1) neće mačka kobasice; violence (1) prebiti kao mačku; conflict (1) slagati se kao pas i mačka; manner (1) gledati kao mače u žižak; quantity (1) ne videti bele mačke.

A cat in English idioms is related to physical appearance too, but also to chaos and disorder, haste, treachery, etc. English idioms based on cats show cats in their relation to some other animals like mouse, dogs and pigeon. All cat idioms in English are classified in the following fields: physical appearance (3) like something that cat brought in, all 
cats are grey in the dark; look what the cat dragged in; anxiety and worry (3) like a hot on a hot tin roof; having kittens, scaredy cat; intensity (3) raining cats and dogs, enough to make a cat laugh, that cat won't jump; power (2) play cat and mouse, fat cat; caution (2) see which way the cat jumps, curiosity killed the cat; having and not having (1) not to have a cat in hell's chance; secrecy (1) let the cat out of the bag; conflict (1) fight like cats and dogs; deception (1) a dead cat bounce; manner (1) grin like a Cheshire cat; equality (1) a cat may look at the king; chaos (1) put the cat among the pigeons; courage (1) bell the cat; haste and speed (1) like a scalded cat; treachery (1) turn cat in pan; happiness (1) like the cat that got the cream; conceit (1) the cat's whiskers; language (1) Has the cat got your tongue; possibility (1) There's more than one way to skin a cat.

Classification made according to these semantic fields could be of great help to translators in filling the translation gaps in the exiting dictionaries. As we have already said, there are 50 English and Serbian animal idioms whose translations could not be found in any dictionaries we used in this study like bell the cat, scaredy cat, a dead cat bounce, enough to make a cat laugh, that cat won't jump, turn cat in pan, dog and a pony show, a shaggy dog story, let the dog see the rabbit, to go to see a man about the dog; ići kao ćorava mačka, žustar kao mačka, lud kao februarski mačak, izvući mačku rep, gnjaviti mačiće, ne bi ga nadlajalo ni devet pasa, izgrditi na pasje obojke, puziti kao pas, tresti se kao kuja u vodenici, držati koliko do pasje šape, nagaziti na pasji sugreb, prosuti pasju corbu. Some of them do exist in the target language but do not contain zoonyms as in to go and see the man about the dog (idem na jedno mjesto, ili gdje i car ide pješke) which is used when you do not want to tell where you are really going, especially when you are going to the toilet.

\section{CONCLUSION}

Idioms reflect the culture of a language and mastering them in the process of studying foreign languages is more than being able to use them efficiently in communication and sound more native like. It is about understanding cultures other than your own. Culturally and linguistically, Serbian and English are different, and we believe that the study of this kind based on idiom analysis and translation would contribute to better inter-cultural and inter-linguistic understanding. Both Serbian and English are rich in idioms, and animal idioms, especially those with cats and dogs, hold a special place in the two languages. In Serbian both, cat and dog idioms mainly connote negative qualities in the field of physical appearance/character, intensity, misfortune. In English, dog and cat idioms also leave a bad taste in mouth since most of them have rather negative meanings. Of course, we could exclude few lonely cases such as like a dog with two tails or like the cat that got the cream. The research we conducted may shed light on this poorly explored area of linguistic studies especially in the field of translatology and cultural studies. We showed which strategies were employed in transferring one idiom from the source language to the target language. We also showed which animal idioms have not been translated yet. The shortcoming of this study is the fact that it is based only on the data found in dictionaries. We hope that the result presented in this paper may arouse the interest of those who want to carry out further exploration in the same field. We also believe that the classification of idioms according to semantic fields will make the job of translators easier and encourage them to fill the existing gaps in translation. 


\section{REFERENCES}

Baker, Mona. 1992. In Other Words: A Coursebook on Translation. London: Routledge.

Gläser, Rosemarie. 1984. "The translation aspect of phraseological units in English and German". Papers and Studies in Contrastive Linguistics 18: p.123-134.

Newmark. Peter. 1981. Approaches to Translation [M]. Shanghai: Shanghai Foreign Language Education Press.

Newmark, Peter. (1988). A textbook of translation. England: Prince Hall International.

Новаковић, Ш. and Ј. Б.Томић (2015). “On Fixed Expressions in Translation”, Зборник

радова са међународног научног скупа” Ново и традиционално у транслатологији и настави руског језика као страног”. Московски државни универзитет Ф.М.Ломоносов, Факултет за превођење/Паневропски универзитет Апеирон, Факултет филолошких наука: p. 488-495.

Varlamova, E.V., A.E. Rakhimova, and A.S., Shingareva,. 2017. "Representation of phraseological units with a zoonym component in the German and English linguistic views of the world". Revista Publicando, 4 No 12. (1): p. 477-485.

\section{DICTIONARIES}

The Oxford Dictionary of Idioms. 2004. (edit.by J. Siefrig). Oxford: Oxford University Press. Cambridge International Dictionary of Idioms. 1998. Cambridge: Cambridge University Press.

Bujas, Željko. 2008. Veliki hrvatsko-engleski rječnik, četvrto izdanje. Zagreb: Nakladni zavod globus.

Drvodelić, Milan.1989. Hrvatsko ili srpsko engleski rječnik. Zagreb: Školska knjiga. Drvodelić, Milan.1990. Englesko-hrvatski ili srpski rječnik. Zagreb: Školska knjiga

Filipović, Rudolf. 1990. English Croatian or Serbian Dictionary. Zagreb: Grafički zavod Hrvatske

Matešić, Josip. 1982. Frazeološki rječnik hrvatskoga ili srpskog jezika. Zagreb: Školska Knjiga.

Милосављевић, Б. and М. Вилијамс-Милосављевић 2007. Српско-енглески речник идиома. Београд: Завод за уџбенике.

Милосављевић, Бошко. 2007. Енглеско-српски фразеолошки речник. Београд: Завод за уџбенике. 